\title{
Ventilated Double Window for the Preheating of the Ventilation Air Comparison of Its Performance in a Northern and a Southern European Climate
}

\author{
Jorge S. Carlos ${ }^{1}$ and Helena Corvacho ${ }^{2}$ \\ ${ }^{1}$ C-MADE, Centre of Materials and Building Technologies, University of Beira Interior, Calçada Fonte do Lameiro, \\ 6201-001 Covilhã, Portugal \\ ${ }^{2}$ Laboratory of Building Physics, Civil Engineering Department, Faculty of Engineering (FEUP), \\ University of Porto, Rua Dr. Roberto Frias, 4200 Porto, Portugal
}

Correspondence should be addressed to Jorge S. Carlos; jcarlos@ubi.pt

Received 21 December 2012; Revised 24 February 2013; Accepted 25 March 2013

Academic Editor: Hikmet Esen

Copyright (C) 2013 J. S. Carlos and H. Corvacho. This is an open access article distributed under the Creative Commons Attribution License, which permits unrestricted use, distribution, and reproduction in any medium, provided the original work is properly cited.

Keeping the indoor air quality within the reference levels requires that the polluted indoor air be replaced by fresh air coming from the outside. This paper presents a sensitivity analysis and a series of simulations where the performance of this passive system is studied. The influence of each relevant factor, like the wind, the solar radiation, and the outdoor air temperature, is assessed. Two different local sets of climatic data were chosen, a mild and a cold winter.

\section{Introduction}

Buildings envelope has been optimized over the last decades assuring a better insulation between the indoors and the outdoors, thus reducing heat transfer through the construction elements. Part of the thermal losses of a building takes place through the necessary renewal of the indoor air to maintain a good air quality for the inhabitants. Increasing thermal resistance of buildings envelope leads to an increasing relative importance of heat losses through ventilation. Those losses may come to represent an important percentage in the overall thermal losses. Energy Research Group [1] points to 20\% to $40 \%$ of heat loss by the renewal of air in homes in central Europe, with an increase to $70 \%$ in buildings well thermally insulated.

Various technologies and building systems have been developed to reduce the impact of climate, thus reducing the energy consumption of buildings. A survey of studies on buildings facades is listed by Quesada et al. [2,3] where active and passive solar facade solutions, either opaque or nonopaque, are presented. Sadineni et al. [4] made a review of building envelope components and respective improvements from an energy efficiency perspective.

Preheating of the ventilation air in winter has also been studied in the last decades. A study was done and a model was proposed by Woods et al. [5] to reduce energy consumption due to ventilation by heating the air through an atrium of large public buildings. In fact, several possible ways of preheating the ventilation air are available. "For a high insulated house or low energy house, the minimum heating requirement should be supplied by heating the supply air in the ventilation system-a system which is necessary in any case," as it was referred by Persson et al. [6].

The unglazed transpired solar collectors [7], the solar air collector mounted on sun-facing walls [8] or on the roof, the ventilated photovoltaic facade [9] with an air channel between the photovoltaic panel and the facade, the ventilated double glazed facade [10], the window air collector [11], the 
supply air window [12], and the ventilated double window [13] are all similar systems in what concerns the modus operandi. These systems can provide a preheating of the ventilation air through an air channel where the stream recovers the available heat provided by the incident solar radiation and also the heat that is lost through the system from inside. Nevertheless, the last four systems have other similarities between them. They allow the view to the outside and the income of solar radiation through the glazing.

For the same purpose, preheating the incoming air, the earth-to-air heat exchangers through buried pipes can be used. Due to the high thermal inertia of the soil, the fluctuation of its temperature is considerably lower than the one observed at the surface. In winter the soil temperature is higher than the outdoor air temperature. Under these conditions the fresh air that passes through the tubes is heated and enters the building at a higher temperature than that found outdoors [14]. Another traditional possibility for preheating ventilation air is the construction of a conservatory attached to the main building, with fresh air entering in it at a low level. The air is preheated within the space and enters the main building through top vents [15].

The ventilated double window is composed of two separate parallel windows being placed in the same facade opening which is capable of preheating passively the rising air within the channel between them under natural ventilation. In Carlos et al. [13], a series of experimental measurements was conducted in a test cell exposed to real outdoor weather conditions in order to characterize its thermal performance. It was found that it is a simple and cheap building technology which can be implemented in both new and existing buildings. Carlos et al. [16] presented a mathematical model to predict the thermal performance of a ventilated double window validated with the use of test facilities. Different configurations of the system were tested and some results of a simulated work based on it were presented. An energy balance of the different configurations was determined concluding that it is an alternative to cold natural ventilation. It was found that the solar collector function plays a small role in the preheating of the fresh air due to its transparency and a few hours of sunshine. The heat recovery function of the heat lost from inside works all day round which makes it suitable on any facade orientation [17].

Windows are the most complex facade component: they are the weakest one, in what concerns thermal resistance, acoustic insulation, and air tightness but they are able, at the same time, to provide access to natural light, a view to the outside, warmth, and fresh air. In the last decades, significant improvements on their thermal performance have been achieved. The ventilated double window was the object of a wide study carried out by the authors of this paper. The system was studied in an experimental facility under real weather conditions [13] and modeled to allow simulations under different realities [16]. The purpose of this paper is to present and discuss the response of this system in function of some influent factors and how those factors affect differently the air flow rate and the incoming air temperature. Simulations under different climatic conditions are also presented and compared.

\section{System Description and Relevant Data}

2.1. The System. The ventilated double window being studied is composed of two separate parallel windows being placed in the same facade opening, being both $6 \mathrm{~mm}$ single transparent glazed casements with a standard white aluminum sash. Each window has $1.40 \mathrm{~m}$ width and $1.10 \mathrm{~m}$ height. The glazing surface is about $62 \%$ of the overall window's surface. A vent (air inlet) with an area of $50 \mathrm{~cm}^{2}$ is installed at the bottom of the outer window and a vent (operable or not) also with an area of $50 \mathrm{~cm}^{2}$ is installed at the top of the inner window. The channel between the two windows is then used as an air path for incoming air flow that passes through those vents shown in Figure 1. The width of the ventilated channel is $7 \mathrm{~cm}$ on average. These basic characteristics were used as a standard to evaluate the potential for preheating the ventilation air during winter time. The outdoor air stream enters into the air channel through the outer window's inlet, rises in the channel between the windows, and enters the room through the inner window's vent. Having been preheated by the heat transferred from indoors through the inner window and by the incident solar radiation, the air is delivered inside at a higher temperature than it would be if it entered the building directly coming from outdoors.

The simulations carried out went through two different phases. Phase 1 focuses on each variable that influences the heat gain of the air passing through the window and the temperature of the incoming air. Phase 2 focuses on the system performance during a whole heating season based on different climatic data files, from a mild to a cold winter, so one can find out where and how this system is the most suitable. The main physical properties of the windows components that were considered in simulations are shown in Table 1.

2.2. Relevant Variables. The inner window of this system is heated up by the heat that is lost from indoors. This and the outer window are both heated up due to incident solar radiation. The outer air that passes through the ventilated air channel between both windows extracts part of the heat stored in the windows by convection. The main heat balance equations are obtained from ISO 15099 [18] which specify detailed calculation procedures to determine the thermal and optical transmission properties of windows including when there is a ventilated cavity. The heat transfer to the passing air can be written as follows:

$$
Q_{g}=A_{i} h_{c_{v}}\left(\theta_{\mathrm{is}}-\theta_{a}\right)-A_{o} h_{c_{v}}\left(\theta_{a}-\theta_{\mathrm{os}}\right)
$$

where $Q_{g}$ represents the total heat gain carried to the indoor environment by the air flow (W), $A_{i}$ and $A_{o}$ are the inner and outer windows areas, respectively $\left(\mathrm{m}^{2}\right), h_{c,}$ is the surfaceto-air heat transfer coefficient by convection for ventilated air channel $\left(\mathrm{W} / \mathrm{m}^{2} \cdot{ }^{\circ} \mathrm{C}\right), \theta_{\text {is }}$ and $\theta_{\text {os }}$ are the temperatures of the inner and outer windows surfaces (facing the air channel), respectively $\left({ }^{\circ} \mathrm{C}\right)$, and $\theta_{a}$ is the equivalent mean temperature of the air in the channel $\left({ }^{\circ} \mathrm{C}\right)$. The convective heat 
transfer coefficient, $h_{c_{v}}$, can be obtained using the following expression:

$$
h_{c_{v}}=2 h_{c}+4 v,
$$

where $h_{c}$ is the surface-to-surface heat transfer coefficient by convection for nonvented cavities $\left(\mathrm{W} / \mathrm{m}^{2} \cdot{ }^{\circ} \mathrm{C}\right)$ and $v$ represents the mean air speed in the channel $(\mathrm{m} / \mathrm{s})$. Naturally, the air velocity in the air channel has a big influence on the resulting convective heat coefficient. Heat transfer to and from the motion air is related to the air speed and also to the air characteristics which are expressed by the Nusselt number. In a nonventilated channel the coefficient $h_{c}$ becomes

$$
h_{c}=\mathrm{Nu} \frac{\lambda}{d},
$$

where $\mathrm{Nu}$ is the Nusselt number, $\lambda$ is the thermal conductivity of the $\operatorname{air}\left(\mathrm{W} / \mathrm{m} \cdot{ }^{\circ} \mathrm{C}\right)$, and $d$ is the distance between surfaces $(\mathrm{m})$. The equivalent mean temperature of the air in the cavity, $\theta_{a}$, is estimated by

$$
\theta_{a}=\theta_{\mathrm{sf}}-\frac{H}{H_{v}}\left(\theta_{d}-\theta_{e}\right),
$$

where $\theta_{\text {sf }}$ is the average temperature of the surfaces of the windows turned to the air channel $\left({ }^{\circ} \mathrm{C}\right), \mathrm{H}$ is the characteristic height (temperature penetration length, in $\mathrm{m}$ ), $H_{v}$ is the height of air channel (m), $\theta_{d}$ is the temperature of the air at the outlet of the channel $\left({ }^{\circ} \mathrm{C}\right)$, and $\theta_{e}$ is the temperature of the incoming air in channel $\left({ }^{\circ} \mathrm{C}\right)$ :

$$
\begin{gathered}
\theta_{\text {sf }}=\frac{\theta_{\text {is }}+\theta_{\mathrm{os}}}{2}, \\
H=\frac{c \rho_{a} d}{2 h_{c_{v}}},
\end{gathered}
$$

where $c$ is the specific heat capacity of the air $\left(\mathrm{J} /\left(\mathrm{kg}^{\circ} \mathrm{C}\right)\right), \rho_{a}$ is the density of the air at temperature $\theta_{a}\left(\mathrm{~kg} / \mathrm{m}^{3}\right)$, and $d$ is the distance between windows (width of the cavity, in $\mathrm{m}$ ). The total heat exchange by radiation between the two parallel windows, within the channel, can be estimated by [19]

$$
Q_{r}=\frac{\sigma\left(T_{\mathrm{is}}^{4}+T_{\mathrm{os}}^{4}\right)}{\left(1-\varepsilon_{1}\right) / \varepsilon_{1} A_{1}+\left(1 / A_{1} F_{12}\right)+\left(1-\varepsilon_{2}\right) / \varepsilon_{2} A_{2}},
$$

where $Q_{r}$ represents the heat transfer by radiation $\left(\mathrm{W} / \mathrm{m}^{2}\right), \sigma$ is the Stefan-Boltzmann's constant $\left(5,729 \times 10^{-8} \mathrm{~W} / \mathrm{m}^{2} \mathrm{~K}^{4}\right)$, $T_{\text {is }}$ and $T_{\mathrm{os}}$ are the absolute temperatures of the window surfaces facing each other in the air channel (K), $\varepsilon_{1}$ and $\varepsilon_{2}$ are those surfaces' emissivity, and $F_{12}$ is the view factor between surfaces. The temperature of the incoming air depends on the amount of heat extracted from the windows surfaces which is dependent on the air flow rate as just seen. That temperature, $\left(\theta_{d}\right.$, in $\left.{ }^{\circ} \mathrm{C}\right)$, can be calculated as follows:

$$
\theta_{d}=\theta_{u}+\frac{Q_{g}}{\rho c V}
$$

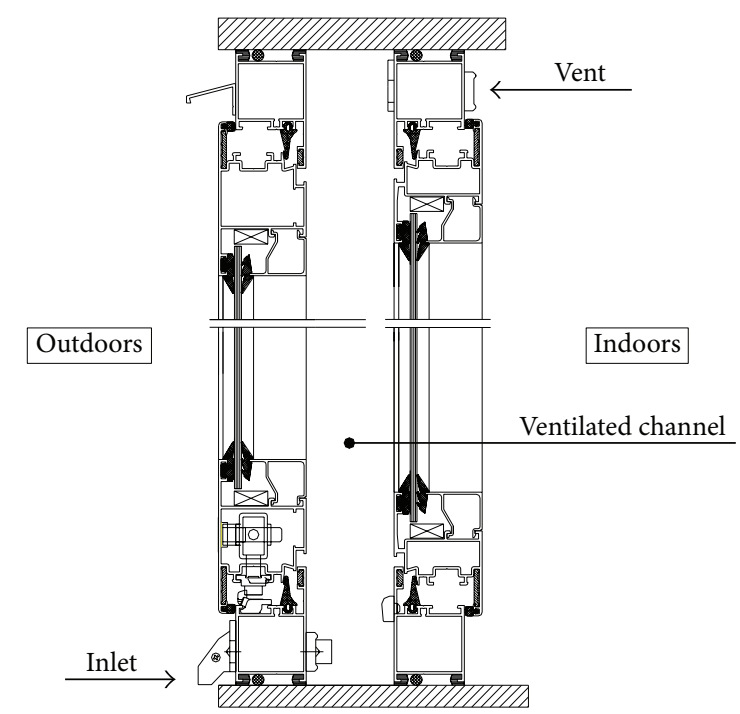

FIGURE 1: Scheme of the ventilated double window.

TABLE 1: Windows components physical properties.

\begin{tabular}{lccc}
\hline & $\begin{array}{c}\text { Heat transfer } \\
\text { coefficient } \\
\left(\mathrm{W} / \mathrm{m}^{2} \cdot{ }^{\circ} \mathrm{C}\right)\end{array}$ & $\begin{array}{c}\text { Solar } \\
\text { absorptance } \\
\alpha\end{array}$ & $\begin{array}{c}\text { Solar } \\
\text { transmittance } \\
\tau\end{array}$ \\
\hline Sash & 5.65 & 0.4 & 0 \\
Glass & 5.7 & 0.14 & 0.74 \\
\hline
\end{tabular}

where, $\theta_{u}$ is the temperature of the outdoor air $\left({ }^{\circ} \mathrm{C}\right)$ and $V$ is the volumetric air flow rate $\left(\mathrm{m}^{3} / \mathrm{s}\right)$.

The amount of heat that the air stream can extract from the windows depends on the available amount of heat stored in the windows which is supplied by two sources. One source is the heat loss from indoors through the inner window and the second is the heat absorbed by both windows due to the incident solar radiation. The heat loss from indoors without solar radiation, $Q_{l}$ (in $\mathrm{W}$ ), can be expressed by the following formula:

$$
Q_{l}=A_{i} U_{i}\left(\theta_{n}-\theta_{a}\right),
$$

where $U_{i}$ is the heat transfer coefficient of the inner window $\left(\mathrm{W} / \mathrm{m}^{2} \cdot{ }^{\circ} \mathrm{C}\right)$ and $\theta_{n}$ is the indoor air temperature $\left({ }^{\circ} \mathrm{C}\right)$. The absorbed solar radiation on both windows can be calculated as follows:

$$
\begin{aligned}
& Q_{o}=I A_{o} \alpha_{o}+Q_{\mathrm{or}}, \\
& Q_{i}=I \tau_{o} A_{i} \alpha_{i}+Q_{\mathrm{ir}},
\end{aligned}
$$

where $Q_{o}$ and $Q_{i}$ are the solar radiation absorbed by the outer and the inner windows, respectively (W), $I$ is the incident solar irradiance $\left(\mathrm{W} / \mathrm{m}^{2}\right), \alpha_{o}$ and $\alpha_{i}$ are the solar absorptance of the outer and the inner windows, respectively, $\tau_{o}$ is the solar transmittance of the outer window, and $Q_{\mathrm{or}}$ and $Q_{\mathrm{ir}}$ are the radiation absorbed by the outer and the inner windows due 
to multiple reflections within the air channel (W), which is given by [20]

$$
\begin{aligned}
& Q_{\mathrm{or}}=\frac{\alpha_{o} \tau_{o} r_{i}}{1-r_{i} r_{o}} I A_{o}, \\
& Q_{\mathrm{ir}}=\frac{\alpha_{o} \tau_{o} r_{i} r_{o}}{1-r_{i} r_{o}} I A_{i},
\end{aligned}
$$

where $r_{o}$ and $r_{i}$ are the solar reflection by the outer and the inner windows, respectively. The total amount of solar radiation that is taken into account [20] depends also on the incident angle of the radiation on the window.

2.3. Wind and Solar Parameters. The ventilated double window system is suitable when natural ventilation is required to enhance indoor air quality. As any natural ventilation system, the obtained ventilation rate depends not only on building characteristics but also on the random conditions of the weather. On a natural ventilated building without any mechanical device, it is obviously not expected to have a constant air flow rate over time. However, in order to minimize unwanted variations of the air flow rate, one must know how buildings and climate interact and which the best strategies to optimize their interaction are.

To preheat the incoming air, the ventilated double window must act as an air inlet. In a natural ventilated building the volumetric air flow rate $\left(V\right.$, in $\left.\mathrm{m}^{3} / \mathrm{s}\right)$ depends on climatic conditions, mainly outdoor air temperature and wind, since it is driven by stack and wind effects. $V$ can be calculated from

$$
V=C_{d} A\left(2 \frac{\Delta P_{t}}{\rho}\right)^{0.5}
$$

where $C_{d}$ is the discharge coefficient (which was considered in this study equal to 0.83 according to a previous experimental work [13]), $A$ is the equivalent area of the openings $\left(\mathrm{m}^{2}\right)$, and $\Delta P_{t}$ represents the total pressure difference combining stack and wind effects $(\mathrm{Pa})$. The pressure difference due to stack effect along the ventilation path $\left(\Delta P_{k}\right.$, in $\left.\mathrm{Pa}\right)$ is determined by

$$
\Delta P_{k}=\Delta \rho g H,
$$

where $\Delta \rho$ represents the air density difference between both sides of each opening $\left(\mathrm{kg} / \mathrm{m}^{3}\right)$ which depends on the air temperatures, $g$ is the acceleration due to gravity $\left(\mathrm{m} / \mathrm{s}^{2}\right)$, and $H$ is the height of the opening in relation to an external reference level $(\mathrm{m})$. The pressure difference due to the wind effect between the air inlet and the air outlet of a certain space $\left(\Delta P_{w}\right.$, in $\left.\mathrm{Pa}\right)$ is expressed as

$$
\Delta P_{w}=0.5\left(C_{p_{e}}-C_{p_{x}}\right) \rho v^{2},
$$

where $C_{p_{e}}$ and $C_{p_{x}}$ are pressure coefficients due to wind at the air inlet and the air outlet of the space, respectively, and $v$ is the mean wind speed $(\mathrm{m} / \mathrm{s})$. The $C_{p}$ values were obtained from Santamouris [21] and are presented in Table 2 for 16 different wind directions (angle with the normal to the surface). The $C_{p}$ value at the outlet of the building (at roof level) is equal to -0.1 .

As previously seen, the performance of the ventilated double window depends also on the solar radiation incident upon the window. To evaluate it, besides the beam intensity, it is important to take the angle of incidence into account. This differs from place to place, and also from day to day and time to time. The angle of incidence of the solar beam on the window (degrees), $i$, is determined by the following expression:

$$
\cos (i)=\cos (\beta) \sin (\nabla)+\sin (\beta) \cos (\nabla) \cos (y),
$$

where $\beta$ is the angle between the window and the horizontal plan (degrees), $\nabla$ is the angle of solar altitude (degrees), and $y$ is the difference between the solar and the window azimuth (degrees). To calculate $h$, the following expression can be used:

$$
\sin (\nabla)=\cos (L) \sin (\delta)+\cos (L) \cos (\delta) \cos (\omega),
$$

where $L$ is the latitude of the place (degrees), $\delta$ is the solar declination angle (degrees), and $\omega$ is the hour angle (degrees), being

$$
\delta=23.45 \sin \left(\frac{360(284+J)}{365}\right),
$$

where $J$ is the day of the year ( 1 to 365 ) and

$$
\omega=15(\mathrm{LST}-12) \text {, }
$$

where LST is the local solar time (hour). The difference between the solar and the window azimuth, $y$, which is expressed by (12), is calculated with the help of expression (13)

$$
y=\left|a_{f}-a_{p}\right|,
$$

where $a_{f}$ is the window azimuth (degrees) and $a_{p}$ is the solar azimuth (degrees) which must be calculated using the following expression:

$$
\cos \left(a_{p}\right)=\frac{\sin (\nabla) \sin (L)-\sin (\delta)}{\cos (\nabla) \cos (L)} .
$$

\section{Results and Discussion}

3.1. General Approach. As explained before, simulations were carried out in two phases. In the first phase, steady environment conditions were assumed. In each simulation set, only one variable was intentionally altered. The results are analyzed in function of the variable in study. This kind of analysis is useful in order to optimize the geometry and the use of the system. The second phase of simulations dealt with real climatic files [22]. Two locations were chosen to compare the system's performances. The first is a Southern European city with mild winter and high solar radiation available in winter, Lisbon (Portugal). The second location is a Northern European city with a cold winter and low solar radiation available, Oslo (Norway). Results for both locations are compared. Indoor environment comfort level (indoor air temperature) in winter is set as recommended by ISO 7730 [23]. 
TABLE 2: Pressure coefficients values [21].

\begin{tabular}{|c|c|c|c|c|c|c|c|c|c|c|c|c|c|c|c|c|}
\hline Angle & 0 & 22.5 & 45 & 67.5 & 90 & 112.5 & 135 & 157.5 & 180 & 202.5 & 225 & 247.5 & 270 & 292.5 & 315 & 337.5 \\
\hline$C_{p}$ & 0.9 & 0.7 & 0.5 & 0.2 & -0.1 & -0.1 & -0.2 & -0.2 & -0.2 & -0.2 & -0.2 & -0.1 & -0.1 & 0.2 & 0.5 & 0.7 \\
\hline
\end{tabular}

\subsection{Phase 1: Sensitivity Analysis}

3.2.1. The Influence of Air Flow Rate. In order to characterize the influence of the variation of the air flow rate, Figure 2 presents the heat gain and the temperature of the incoming air in function of the air flow rate, when outdoor air temperature is $0^{\circ} \mathrm{C}$, with and without solar radiation.

The highest air flow rate corresponds to the highest value of the amount of heat carried by the air stream. However the variation of the heat gain is not linear with the increase of the volumetric air flow rate. The passing air through the channel removes heat from the inner window surface and at the same time loses heat to the outer window surface when its temperature is somewhere between both windows surface temperatures. As it can be seen, the temperature of the incoming air decreases with the increase of the air flow rate. When air speed gets higher within the channel, the air has less time in contact with the windows surfaces to heat up, but since a greater quantity of air is passing through the channel per unit of time, a greater amount of heat per unit of time is carried inside by the air stream. However it is important to notice that the higher the air flow rate, the lower the ratio between heat gain and air flow rate.

For example, for an air flow rate of $25 \mathrm{~m}^{3} / \mathrm{h}$ the temperature reached by the air stream is $5.1^{\circ} \mathrm{C}$. The heat gain is $44 \mathrm{~W}$ which corresponds to $1.8 \mathrm{Wh} / \mathrm{m}^{3}$. For a higher air flow rate, for example, $75 \mathrm{~m}^{3} / \mathrm{h}$, the temperature reached by the air stream is only $2.4^{\circ} \mathrm{C}$. The heat gain increases to $62 \mathrm{~W}$, but this means a gain of only $0.8 \mathrm{Wh} / \mathrm{m}^{3}$. The $h_{c_{v}}$ is $4.14 \mathrm{~W} / \mathrm{m}^{2 \circ} \mathrm{C}$ and $4.56 \mathrm{~W} / \mathrm{m}^{2 \circ} \mathrm{C}$, respectively.

In Figure 2, it can be observed also that the effect of solar radiation is more significant, in terms of temperature of the incoming air, if the air flow rate is low, as it could be expected, but, in what concerns the heat gain per hour, the opposite occurs.

3.2.2. The Influence of Outdoor Air Temperature. At a constant air flow rate of $50 \mathrm{~m}^{3} / \mathrm{h}$, the incoming air temperature increases linearly with the increase of the outdoor air temperature as shown in Figure 3. The former goes from $5.1^{\circ} \mathrm{C}$ higher than outdoor air temperature when the temperature difference between indoors and outdoors is $32^{\circ} \mathrm{C}$ to $0.2^{\circ} \mathrm{C}$ higher than outdoor air temperature for a difference of $2^{\circ} \mathrm{C}$, without solar radiation. By adding $500 \mathrm{~W} / \mathrm{m}^{2}$ of perpendicular incident solar radiation, the incoming air temperature is $7.6^{\circ} \mathrm{C}$ higher than outdoor air temperature for a temperature difference between indoors and outdoors of $32^{\circ} \mathrm{C}$ and $2.1^{\circ} \mathrm{C}$ for a difference of $2^{\circ} \mathrm{C}$. The $h_{c_{v}}$ and therefore the heat gain reduce while outdoor air temperature increases. As the latter raises, the thermal losses through the window decrease, so the available heat to be recovered by the passing air also decreases. The heat gain goes from $92 \mathrm{~W}$ and $138 \mathrm{~W}$ (without

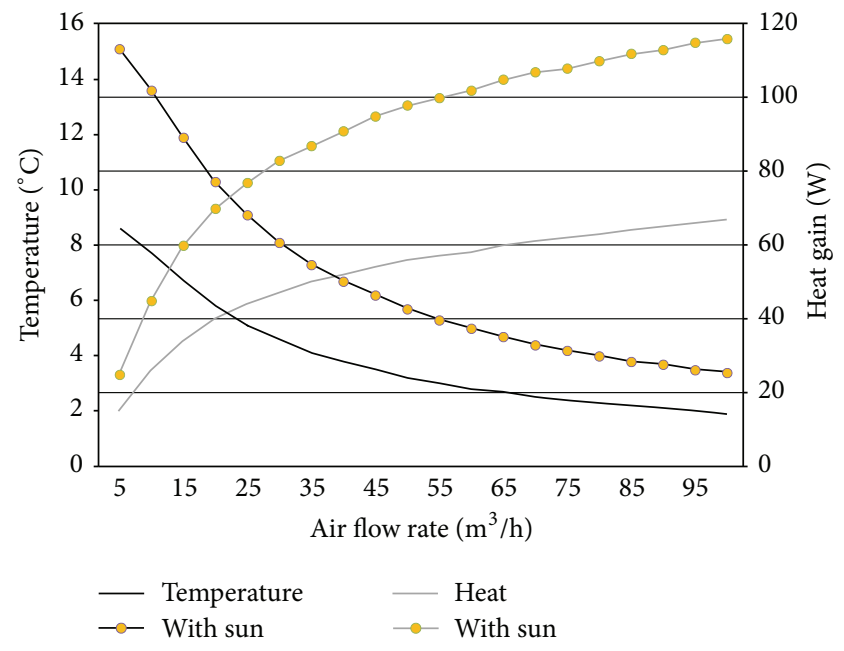

FIGURE 2: Heat gain and temperature of the incoming air in function of the air flow rate for an outdoor air temperature of $0^{\circ} \mathrm{C}$.

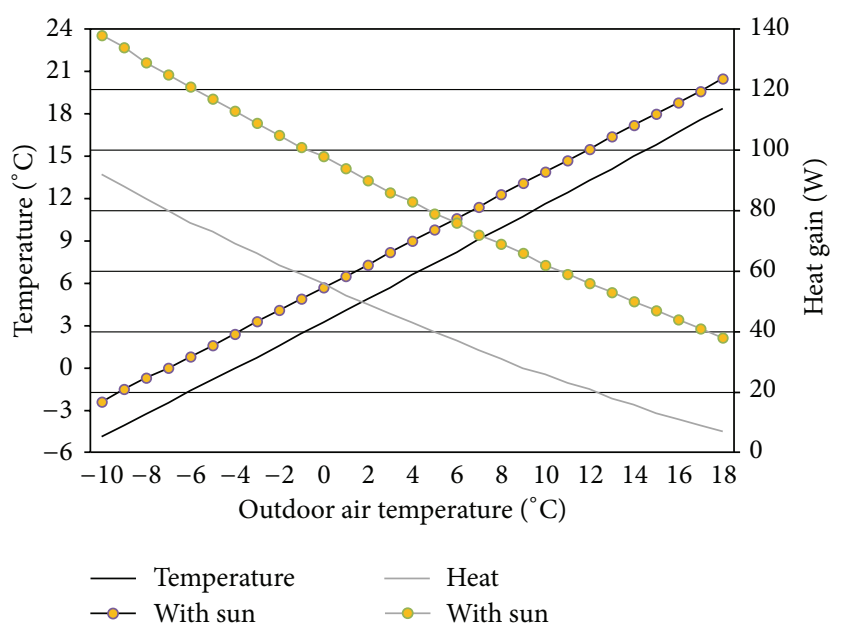

FIGURE 3: Heat gain and temperature of the incoming air in function of the outdoor air temperature, for a constant air flow rate of $50 \mathrm{~m}^{3} / \mathrm{h}$.

and with sun), for a temperature difference between indoors and outdoors of $32^{\circ} \mathrm{C}$, to $3 \mathrm{~W}$ and $32 \mathrm{~W}$, for a temperature difference between indoors and outdoors of $2^{\circ} \mathrm{C}$.

3.2.3. The Influence of Incident Solar Radiation. As observed in Figures 2 and 3, when solar radiation falls on the window, the heat gain and the temperature of the incoming air increase regardless of the air flow rate and of the outdoor air temperature. Figure 4 shows the variation of the heat gain and of the temperature of the incoming air for two different air flow rates $\left(25 \mathrm{~m}^{3} / \mathrm{h}\right.$ and $\left.75 \mathrm{~m}^{3} / \mathrm{h}\right)$ and an outdoor 
air temperature of $0^{\circ} \mathrm{C}$. The heat gain and the incoming air temperature have a linear increasing tendency while solar radiation increases.

\subsection{Phase 2: Comparative Study for Two Different Climates.} A second phase of simulations was performed in order to evaluate the double window behavior during the months of the heating season, that is, the period from October to May [24]. The simulations were carried out using two climatic data files (Building Technologies Program from the US Department of Energy) which correspond to Lisbon (Portugal), moderately cold in winter, and Oslo (Norway), a significantly colder climate. These two cities, Lisbon and Oslo, represent for the purpose of this study the Southern Mediterranean climate and the North European Coastal climate [22].

Several strategies may be followed to increase or decrease indoor air changes per hour, according to the air quality requirements of a building. Under a random weather, the characteristics of the building, its location, its orientation, and also the characteristics of its facade components must be carefully studied to comply with the different needs in what concerns indoor air renovation. The aim of a ventilated double window is to preheat the ventilation air before it is delivered inside the building, so one direction of the air stream along the air channel is to be expected (from the outside to the inside). In order to reduce the possibilities of an inversion of the air stream through the ventilated double window system, a vertical exhaust duct technique was used in the simulations. The building chosen for this analysis is a two-floor detached house with a ventilated double window installed at the ground floor level.

Since the studied window system is used to preheat the incoming air, it is only useful during winter. During summer or cooling season, users are expected to open the outer window or even both windows for natural ventilation. In the same way, when the outdoor air temperature reaches the comfort level, as defined by ISO 7730 [23], it is assumed that the outer window is opened, and therefore, there is no preheating of the incoming air. Following this criterion, during the period under analysis in the second phase of simulations, especially in mid-season (October and November or April and May) there were moments when the preheating of the incoming air was not taken into account. More details on this will be given in the following (Figure 7).

For the two studied climates, two different orientations of the facade were considered, facing due North and facing due South, in order to characterize the effect of the lowest and the highest available incident solar radiation. For the same wind speed different wind directions have different results on both window orientations. The overall results are presented and the performances are compared for the same building. The values of air flow rate, heat gain, and temperature of the incoming air are calculated.

The climatic data used in the simulations are briefly presented in Figures 5, 6, and 7. Figure 5 shows the monthly mean values of wind speed $(\mathrm{m} / \mathrm{s})$ and outdoor air temperature $\left({ }^{\circ} \mathrm{C}\right)$, in Lisbon and in Oslo, for the months considered in the

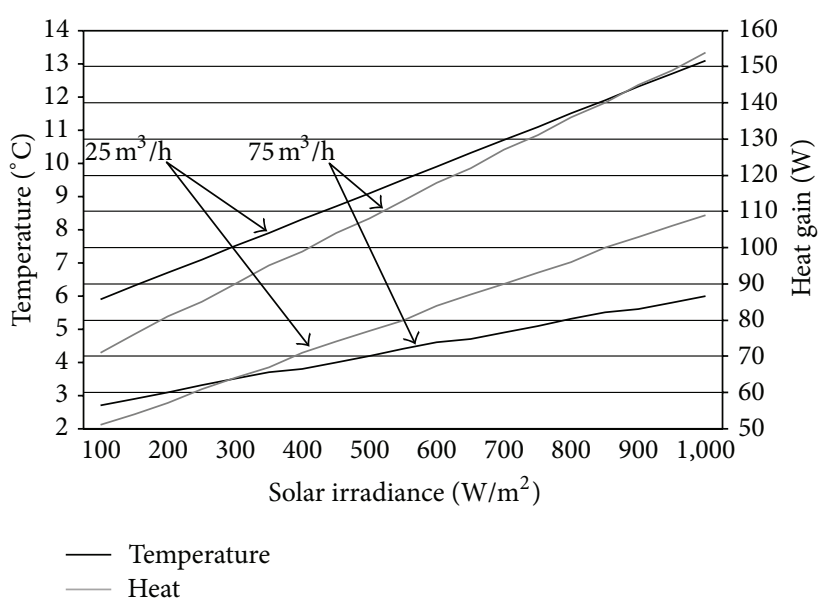

FIGURE 4: Heat gain and temperature of the incoming air in function of the solar irradiance, for air flow rates of $25 \mathrm{~m}^{3} / \mathrm{h}$ and $75 \mathrm{~m}^{3} / \mathrm{h}$ and an outdoor air temperature of $0^{\circ} \mathrm{C}$.

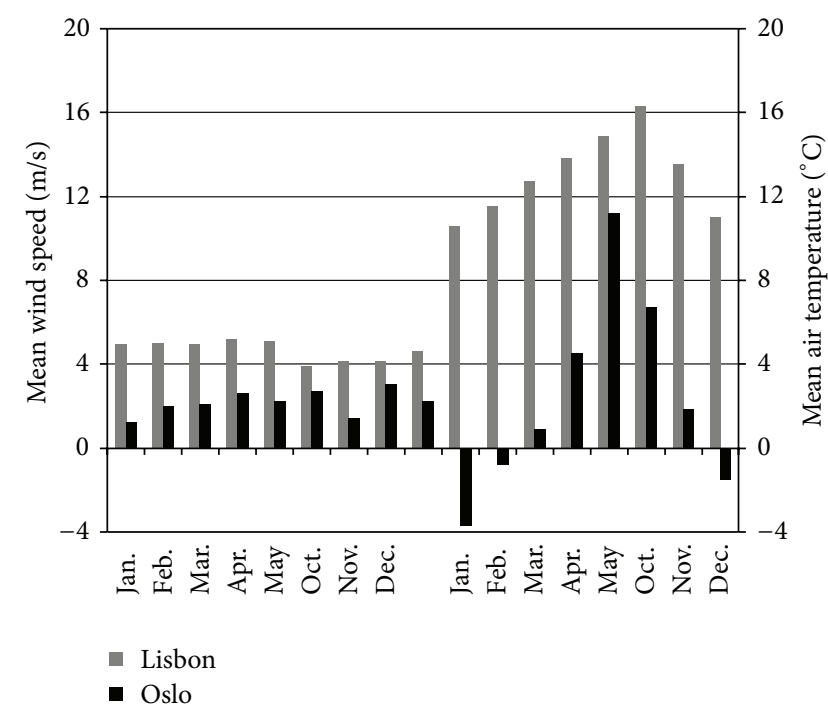

FIGURE 5: Monthly mean values of wind speed and outdoor air temperature in Lisbon and Oslo.

simulations. As it can be observed, the wind speed is clearly higher in Lisbon than in Oslo. Outdoor air temperature is, as it could be expected, also higher in Lisbon, being the lowest temperature in Lisbon close to the highest in Oslo, approximately $11^{\circ} \mathrm{C}$.

Figure 6 shows the mean wind direction frequency for both cities.

Figure 7 presents the monthly global solar irradiation on horizontal surface available in Lisbon and Oslo. The available solar irradiation is always higher in Lisbon than in Oslo, as it could be expected, but there is the need to make here a distinction between available irradiation and useful irradiation, in what concerns the preheating of the ventilation air. On the left side of Figure 7, the values of irradiation, directly calculated from the hourly values of irradiance given by the climatic data files, are presented. On the graph of 


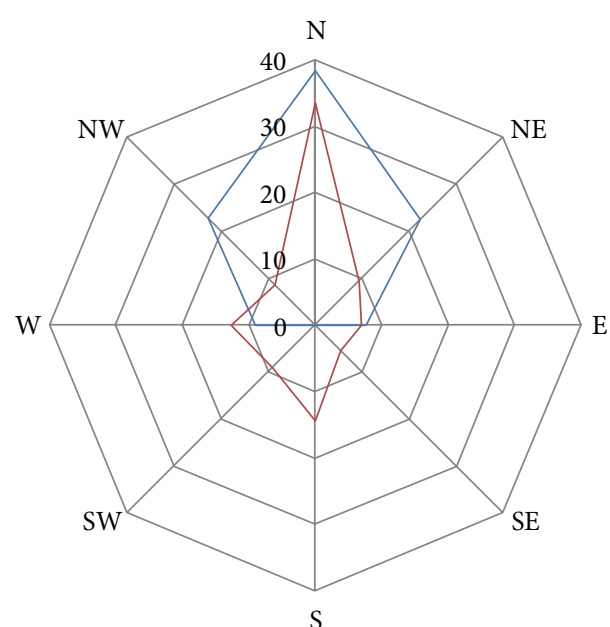

Frequency (\%)

L Lisbon

- Olso

FIGURE 6: Mean wind direction frequency.

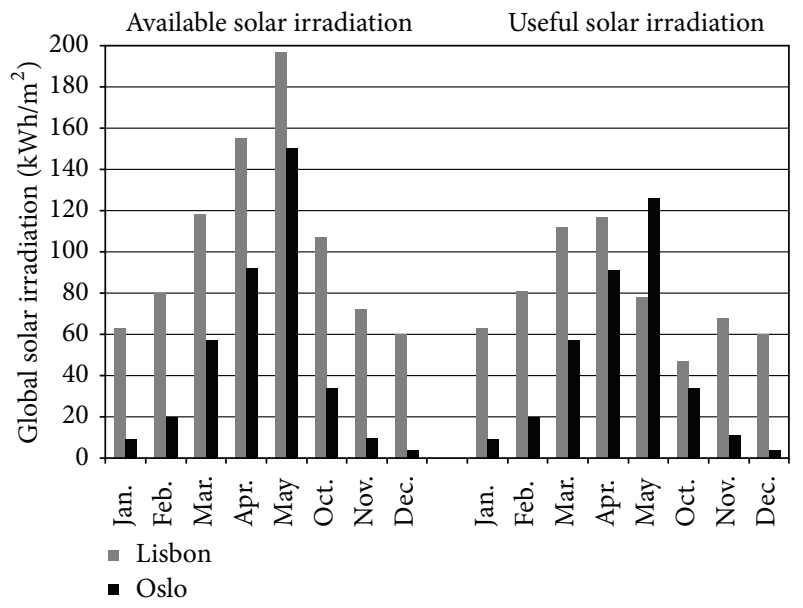

FIGURE 7: Global solar irradiation, on horizontal surface, in Lisbon and Oslo.

the right side of Figure 7, the hourly values of irradiance that correspond to periods of time where the preheating system is deactivated were disregarded, in the calculation of irradiation. The system is deactivated each time the outdoor air temperature is equal to or greater than the comfort indoor air temperature. The values of irradiation obtained this way are the useful part of it. This fact explains, for instance, why in May the graph shows a lower value of irradiation for Lisbon than for Oslo.

Figure 8 shows the results of the simulations for Lisbon. Monthly mean values of the air flow rate $\left(\mathrm{m}^{3} / \mathrm{h}\right)$ and the incoming air temperature $\left({ }^{\circ} \mathrm{C}\right)$ are given, for North and South facing windows. The monthly total heat gain is also provided. The air flow rate is considerably higher for the North facing window. This reflects the North wind predominance (Figure 5). The temperature reached by the passing air is

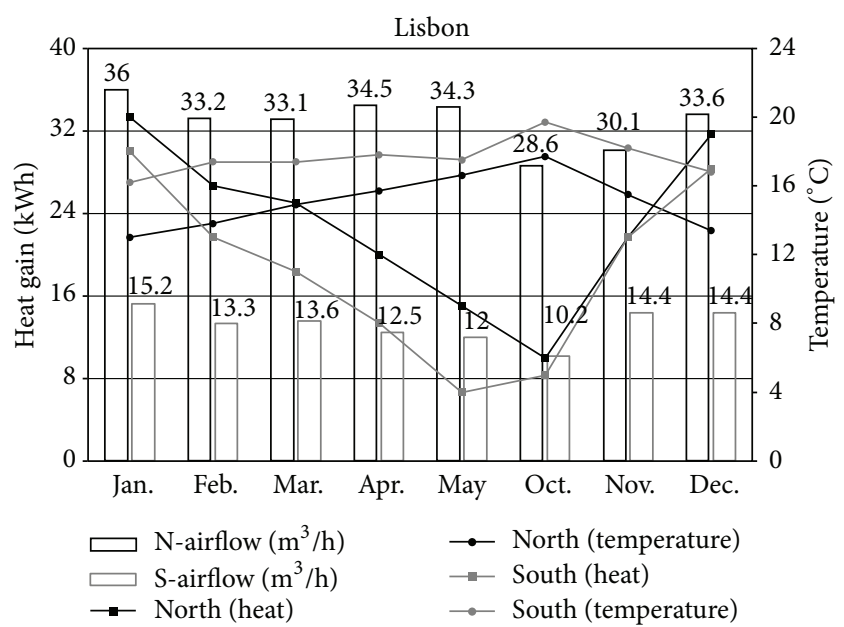

FIGURE 8: Monthly mean values of air flow rate and temperature of the incoming air and monthly total heat gain in Lisbon.

always higher when the window faces due South due to the higher incident solar radiation. During the months of May and October the heat gain of the system is the lowest of the season, for both window orientations. This corresponds to shorter periods of time with the system being active and also to lower temperature differences between indoors and outdoors and therefore lower heat losses from inside.

Figure 9 presents the results for Oslo. As it can be observed, the values of the air flow rate are not much influenced by the window orientation. The stack effect is clearly predominant in Oslo where the temperature difference between indoors and outdoors is much higher than in Lisbon. Because of this higher difference, heat gain through the passing air is also considerably higher in Oslo. In what concerns the temperature of the incoming air, the influence of the window orientation is not so significant in Oslo than it is in Lisbon. With less available solar radiation, the thermal losses from indoors are the most important source of heat to the air stream and these losses do not depend on the orientation of the window.

The overall results of the eight-month period under analysis are presented and compared in Table 3 . The mean value of the air flow rate, the total heat gain, the mean value of the incoming air temperature, and also the air temperature rise provided by the ventilated double window (in comparison to the outdoor air temperature) are presented. The air flow rate is on average higher in Oslo where the wind speed is lower, but the temperature difference between indoors and outdoors is higher (Figure 5). For a higher air flow rate, the heat gain (mainly recovered from the inside) is higher in Oslo. The temperature of the incoming air is higher in Lisbon, but it is in the colder climate of Oslo where the system is able to provide a higher rise of the air temperature.

The present study was performed with a standard ventilated double window described in Section 2.1. Different characteristics of the system as, for example, different areas of vents or different types of glass or a different frame to glass ratio, among other possibilities, would have led to a slightly 
TABLE 3: Monthly results under different climatic conditions.

\begin{tabular}{|c|c|c|c|c|c|c|c|c|c|}
\hline & & \multicolumn{2}{|c|}{$\begin{array}{l}\text { Mean value of air flow rate } \\
\qquad\left(\mathrm{m}^{3} / \mathrm{h}\right)\end{array}$} & \multicolumn{2}{|c|}{$\begin{array}{l}\text { Total heat gain } \\
\quad(\mathrm{kWh})\end{array}$} & \multicolumn{2}{|c|}{$\begin{array}{c}\text { Mean value of incoming } \\
\text { air temperature } \\
\left({ }^{\circ} \mathrm{C}\right)\end{array}$} & \multicolumn{2}{|c|}{$\begin{array}{c}\text { Mean value of air } \\
\text { temperature rise } \\
\left({ }^{\circ} \mathrm{C}\right)\end{array}$} \\
\hline & & North & South & North & South & North & South & North & South \\
\hline \multirow{8}{*}{ Lisbon } & Jan & 36.0 & 15.2 & 20 & 18 & 13.0 & 16.2 & 2.4 & 5.6 \\
\hline & Feb & 33.2 & 13.3 & 16 & 13 & 13.8 & 17.4 & 2.3 & 5.9 \\
\hline & Mar & 33.1 & 13.6 & 15 & 11 & 14.9 & 17.4 & 2.2 & 4.7 \\
\hline & Apr & 34.5 & 12.5 & 12 & 8 & 15.7 & 17.8 & 1.9 & 4.0 \\
\hline & May & 34.3 & 12 & 9 & 4 & 16.6 & 17.5 & 1.7 & 2.6 \\
\hline & Oct & 28.6 & 10.2 & 6 & 5 & 17.7 & 19.7 & 1.4 & 3.4 \\
\hline & Nov & 30.1 & 14.4 & 13 & 13 & 15.5 & 18.2 & 2.0 & 4.7 \\
\hline & Dec & 33.6 & 14.4 & 19 & 17 & 13.4 & 16.8 & 2.4 & 5.8 \\
\hline \multirow{8}{*}{ Oslo } & Jan & 35.2 & 35.5 & 58 & 62 & 2.5 & 2.8 & 6.2 & 6.5 \\
\hline & Feb & 33.7 & 34.9 & 44 & 48 & 4.8 & 5.3 & 5.6 & 6.1 \\
\hline & Mar & 32.0 & 33.8 & 44 & 51 & 6.2 & 7.0 & 5.3 & 6.1 \\
\hline & Apr & 30.9 & 29.6 & 33 & 39 & 8.9 & 10.0 & 4.4 & 5.5 \\
\hline & May & 22.9 & 24.3 & 16 & 22 & 14.2 & 15.4 & 3.0 & 4.2 \\
\hline & Oct & 18.7 & 32.9 & 21 & 33 & 11.5 & 11.1 & 4.8 & 4.4 \\
\hline & Nov & 20.1 & 31.6 & 32 & 42 & 8.2 & 7.2 & 6.4 & 5.4 \\
\hline & Dec & 26.0 & 35.7 & 45 & 53 & 5.0 & 4.2 & 6.5 & 5.7 \\
\hline
\end{tabular}

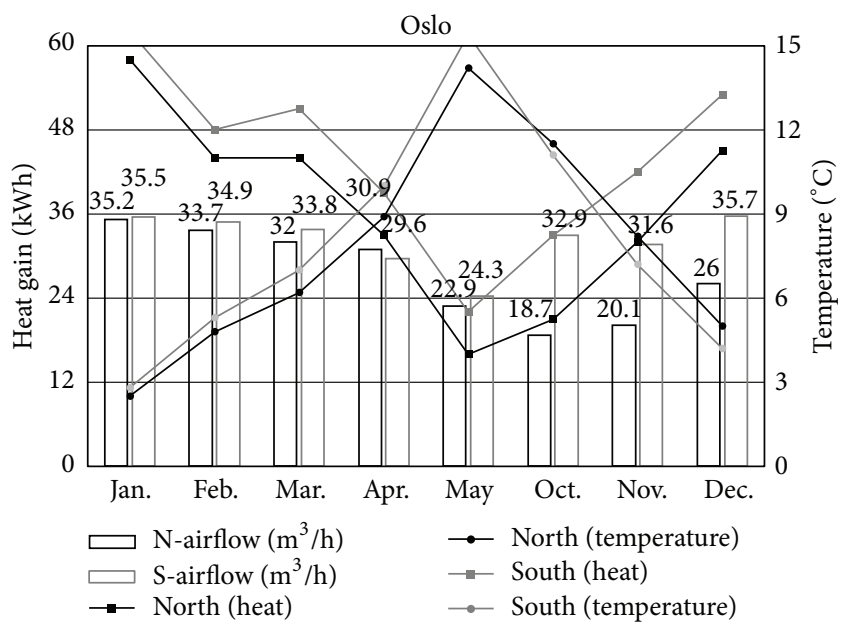

FIGURE 9: Monthly mean values of air flow rate and temperature of the incoming air and monthly total heat gain in Oslo.

different performance of the system. In a wider analysis which falls outside of the scope of this paper, the authors described those variations.

In a building, the air renovation must be guaranteed in order to insure indoor air quality. Being the ventilated double window a part of the ventilation system, some adjustments are possible (and even desirable) as long as the air renovation is not compromised. Admitting that air renovation is guaranteed by a sufficient number of windows or by other means, taking into account the results in Table 3 , two simple examples of adjustments to the standard window under analysis are evaluated as follows.
In the case of Oslo, where thermal comfort may be improved by increasing the temperature of the incoming air, the user may, for instance, close the vent of the inner window in about half way when facing North. With half the area of air inlet, the air flow rate is expected to be reduced, raising the air temperature. In Lisbon, where the temperature of the air stream is higher, it may be interesting to increase the air flow rate in order to comply more easily with the air renovation needs, mainly in the window facing South, for which the air flow rate was found to be quite low. In this case, a doubled area of vent is considered. The overall results of the eight-month period under analysis, after the described adjustments, are presented and compared in Table 4.

In Oslo, with half the area of vent, the air flow rate suffers a maximum reduction in January, less than $17 \mathrm{~m}^{3} / \mathrm{h}$, and a mean reduction for the whole period of about $7.4 \mathrm{~m}^{3} / \mathrm{h}$. The mean temperature of the incoming air increases to $2.8^{\circ} \mathrm{C}$ in January. The mean value of this increase is, for the eight months, of about $2.1^{\circ} \mathrm{C}$.

In Lisbon, for the same window geometry but doubling the vents when facing South, the seasonal mean air flow rate increases to $10.7 \mathrm{~m}^{3} / \mathrm{h}$, with a mean reduction of $1.3^{\circ} \mathrm{C}$ of the air temperature. Depending on the whole ventilation system, these simple adjustments, either in Oslo or in Lisbon, could be interesting options.

\section{Conclusions}

In order to provide indoor air quality within healthy reference levels, indoor polluted air must be removed and replaced by fresh air carried in from the exterior. Whether this is done by a mechanical ventilator or by a natural process, the extracted 
TABLE 4: Monthly results under different climatic conditions, after adjustments of the system.

\begin{tabular}{|c|c|c|c|c|c|c|c|c|c|}
\hline & & \multicolumn{2}{|c|}{$\begin{array}{l}\text { Mean value of air flow rate } \\
\qquad\left(\mathrm{m}^{3} / \mathrm{h}\right)\end{array}$} & \multicolumn{2}{|c|}{$\begin{array}{l}\text { Total heat gain } \\
(\mathrm{kWh})\end{array}$} & \multicolumn{2}{|c|}{$\begin{array}{c}\text { Mean value of incoming } \\
\text { air temperature } \\
\left({ }^{\circ} \mathrm{C}\right)\end{array}$} & \multicolumn{2}{|c|}{$\begin{array}{c}\text { Mean value of air } \\
\text { temperature rise } \\
\left({ }^{\circ} \mathrm{C}\right)\end{array}$} \\
\hline & & North & South & North & South & North & South & North & South \\
\hline \multirow{8}{*}{ Lisbon } & Jan & & 26.9 & & 23 & & 14.7 & & 4.1 \\
\hline & Feb & & 24.1 & & 18 & & 15.9 & & 4.4 \\
\hline & Mar & & 24.9 & & 15 & & 16.1 & & 3.4 \\
\hline & Apr & & 25.3 & & 11 & & 16.4 & & 2.6 \\
\hline & May & & 21.4 & & 5 & & 16.7 & & 1.8 \\
\hline & Oct & & 18.1 & & 6 & & 18.7 & & 2.4 \\
\hline & Nov & & 25.7 & & 16 & & 16.9 & & 3.4 \\
\hline & Dec & & 24.4 & & 21 & & 15.4 & & 4.4 \\
\hline \multirow{8}{*}{ Oslo } & Jan & 18.2 & & 44 & & 5.3 & & 9.0 & \\
\hline & Feb & 17.4 & & 33 & & 7.3 & & 8.1 & \\
\hline & Mar & 16.5 & & 33 & & 8.6 & & 7.7 & \\
\hline & Apr & 15.9 & & 24 & & 10.9 & & 6.4 & \\
\hline & May & 12.1 & & 12 & & 15.5 & & 4.3 & \\
\hline & Oct & 9.8 & & 15 & & 13.0 & & 6.3 & \\
\hline & Nov & 10.5 & & 22 & & 10.2 & & 8.4 & \\
\hline & Dec & 13.5 & & 32 & & 7.4 & & 8.9 & \\
\hline
\end{tabular}

air always removes heat from the inside. Whenever the outdoor air temperature is lower than the indoor air temperature, the ventilation process leads inevitably to thermal losses. Moreover, the incoming air, under natural ventilation, enters the building at outdoor temperature. Besides the energy consumption needed to heat up the arriving air, thermal discomfort may be felt by users. Preheating the ventilation air before it enters the building, by a passive technique, is one of the possible strategies towards an efficient building, reducing energy consumption and enhancing thermal comfort. The ventilated double window is, in a certain measure, capable of this task being suitable in new and existing buildings. In the latter, it is a low cost renovation measure and easy to bring in. The performance of this passive system depends on the geometry of the building and of the system itself, its location and orientation, the climatic conditions, and also the physical properties of its components. After the installation, the user may be allowed to have some control over its working conditions through the use of an operable vent at the top of the inner window allowing more or less air to come in.

In a natural ventilated double window, the obtained air flow rate depends on the wind speed, the inlet and the outlet wind-pressure coefficients, and also the temperature difference between indoors and outdoors. For a fixed indoor air temperature, the air flow rate depends strongly on the outdoor air temperature. Two heat sources contribute to preheating of the passing air within the air channel, thermal losses through the inner window, and incident solar radiation. The amount of heat gained by the air depends also on the air flow rate. The air flow rate and its temperature can be, in a certain measure, controlled by the user. For the same environmental conditions, by operating the vent, the air flow rate can be increased or reduced. By increasing the air flow rate, the air temperature decreases. From the results presented in this paper and for 0.6 air changes per hour, one may say that the studied standard window can fit rooms from $8 \mathrm{~m}^{2}$ to $21 \mathrm{~m}^{2}$ of floor area.

In spite of the occurrence of a mean higher wind speed in Lisbon, the air flow rate through the system was more constant in Oslo and even higher when considering both window orientations. This reveals the importance of the stack effect since the temperature difference between indoors and outdoors is much higher in Oslo than in Lisbon. For the analyzed eight-month period, Oslo has a mean value of outdoor air temperature of $2.4^{\circ} \mathrm{C}$ and Lisbon has a mean value of $13.0^{\circ} \mathrm{C}$. In Lisbon the mean air flow rate through the window is of $27.5 \mathrm{~m}^{3} / \mathrm{h}$ when the window is facing the predominant wind (North). On the other hand, Oslo has a higher air flow rate when the window faces South, being the wind frequency from that direction of only $14 \%$.

Solar radiation plays a relatively modest role in the performance of the ventilated double window. In fact, most of the incident radiation is directly transmitted inside through the transparent glazing. While in Lisbon, with a high available irradiation, the mean rise of the ventilation air temperature is of $2.0^{\circ} \mathrm{C}$, for the window facing North, and $4.6^{\circ} \mathrm{C}$, for the window facing South, Oslo has a mean air temperature rise of $5.3^{\circ} \mathrm{C}$ and $5.5^{\circ} \mathrm{C}$, respectively.

By controlling the inner vent, the user may reduce or increase the incoming air flow rate. In Oslo, a reduction of 
the air flow rate may be interesting to obtain a higher air temperature. In Lisbon, where the delivered air temperature is less important to comfort, the vents may be enlarged to increase the air flow rate. So one can conclude that the ventilated double window may be an interesting and adaptable passive air heating system on any facade orientation and in any temperate to cold location.

\section{Nomenclature}

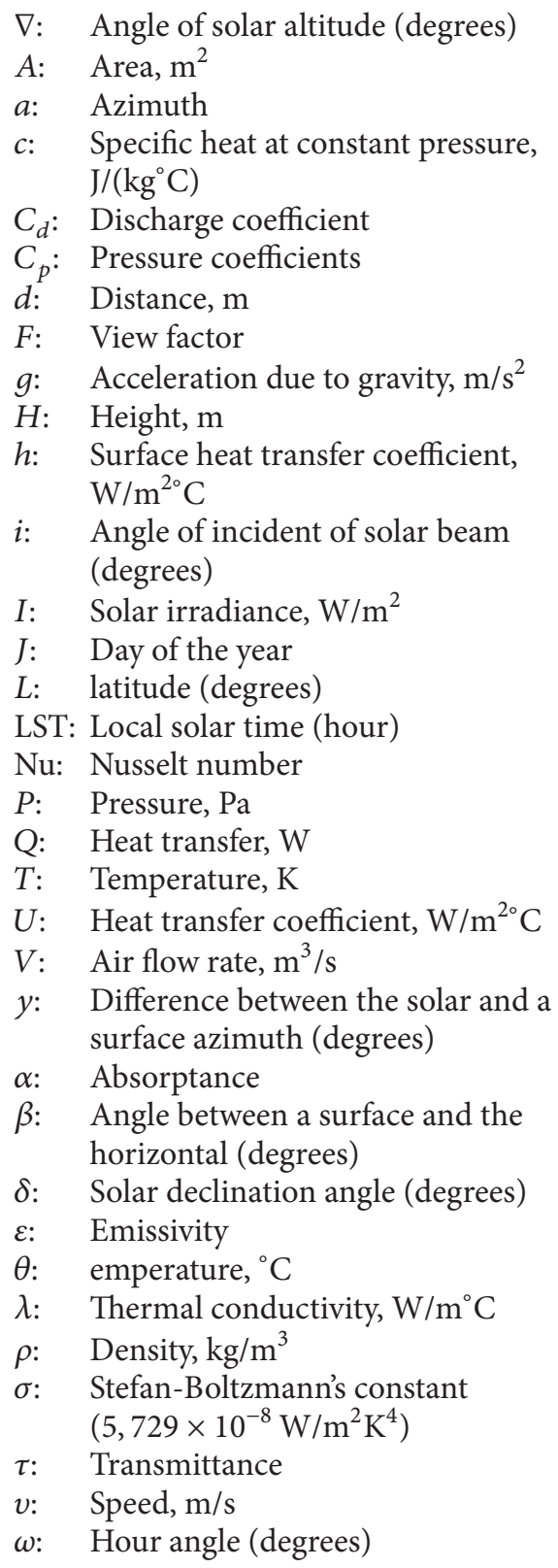

\section{Subscript}
a: Air
c: Convection
$d$ : Delivered
$e$ : Inlet
$f$ : Window
$g$ : Gain
i: Inner
$k$ : Stack
l: Loss
$n$ : Indoor
o: Outer
p: Solar
$r$ : Radiation
$s$ : Surface
$t$ : Total
$u$ : Outdoor
$v$ : Ventilated
$w$ : Wind
$x$ : Outlet

\section{References}

[1] UCD Energy Research Group, "Active solar air heating systems. School of Architecture, Landscape \& Civil Engineering," 2010, http://erg.ucd.ie.

[2] G. Quesada, D. Rousse, Y. Dutil, M. Badache, and S. Hallé, "A comprehensive review of solar facades. Transparent and translucent solar facades," Renewable and Sustainable Energy Reviews, vol. 16, pp. 2643-2651, 2012.

[3] G. Quesada, D. Rousse, Y. Dutil, M. Badache, and S. Hallé, "A comprehensive review of solar facades. Opaque solar facades," Renewable and Sustainable Energy Reviews, vol. 16, pp. 28202832, 2012.

[4] S. B. Sadineni, S. Madala, and R. F. Boehm, "Passive building energy savings: a review of building envelope components," Renewable and Sustainable Energy Reviews, vol. 15, no. 8, pp. 3617-3631, 2011.

[5] A. W. Woods, S. Fitzgerald, and S. Livermore, "A comparison of winter pre-heating requirements for natural displacement and natural mixing ventilation," Energy and Buildings, vol. 41, no. 12, pp. 1306-1312, 2009.

[6] M. L. Persson, A. Roos, and M. Wall, "Influence of window size on the energy balance of low energy houses," Energy and Buildings, vol. 38, no. 3, pp. 181-188, 2006.

[7] D. Summers, J. Mitchell, S. Klein, and W. Beckman, "Thermal simulation and economic assessment of unglazed transpired solar collector systems," in Proceedings of Solar Conference, American Solar Energy Society, 1996.

[8] K. Pottler, C. M. Sippel, A. Beck, and J. Fricke, "Optimized finned absorber geometries for solar air heating collectors," Solar Energy, vol. 67, no. 1-3, pp. 35-52, 1999.

[9] G. Y. Yun, M. McEvoy, and K. Steemers, "Design and overall energy performance of a ventilated photovoltaic façade," Solar Energy, vol. 81, no. 3, pp. 383-394, 2007.

[10] D. M. M. Arons and L. R. Glicksman, "Double skin, airflow facades: will the popular European model work in the USA?" Building Technology Program, Massachusetts Institute of Technology, 2003.

[11] C. Filleux, "Window air collectors," in Solar Air Systems-A Design Handbook, International Energy Agency (IEA), James \& James, London, UK, 2000.

[12] M. E. McEvoy, R. G. Southall, and P. H. Baker, "Test cell evaluation of supply air windows to characterise their optimum 
performance and its verification by the use of modelling techniques," Energy and Buildings, vol. 35, no. 10, pp. 1009-1020, 2003.

[13] J. S. Carlos, H. Corvacho, P. D. Silva, and J. P. Castro-Gomes, "Real climate experimental study of two double window systems with preheating of ventilation air," Energy and Buildings, vol. 42, no. 6, pp. 928-934, 2010.

[14] M. De Paepe and A. Janssens, "Thermo-hydraulic design of earth-air heat exchangers," Energy and Buildings, vol. 35, no. 4, pp. 389-397, 2003.

[15] N. Lechner, Heating, Cooling, Lighting_Design Methods for Architects, John Wiley \& Sons, 1991.

[16] J. S. Carlos, H. Corvacho, P. D. Silva, and J. P. Castro-Gomes, "Modelling and simulation of a ventilated double window," Applied Thermal Engineering, vol. 31, no. 1, pp. 93-102, 2011.

[17] J. Carlos, H. Corvacho, P. Silva, and J. Castro-Gomes, "Heat recovery versus solar collection in a ventilated double window," Applied Thermal Engineering, vol. 37, pp. 258-266, 2012.

[18] ISO 15099, "Thermal Performance of Windows, Doors and Shading Devices-Detailed Calculations," International Organization for Standardization, 2003.

[19] J. A. Duffie and W. A. Beckman, Solar Engineering of Thermal Process, John Wiley \& Sons, 2006.

[20] C. Park, Occupant responsive optimal control of smart façade system [Ph.D. thesis], College of Architecture, Georgia Institute of Techonoly, 2003.

[21] M. Santamouris, "Prediction methods," in Natural Ventilation in Buildings, Ch 3, James \& James, 1998.

[22] CEC-Commission of the European Communities, Energy in Architecture-The European Passive Solar Handbook, B. T. Batsford Limited, London, UK, 1993.

[23] ISO 7730, "Moderate thermal environments-determination of the PMV and PPD indices and specification of the conditions for thermal comfort," International Organization for Standardization, 1994.

[24] EN 832, "Thermal performance of buildings-Calculation of energy use for heating-Residential buildings," European Committee for Standardization, 1998. 


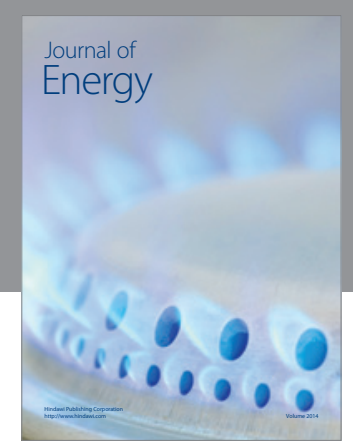

Journal of

Industrial Engineering
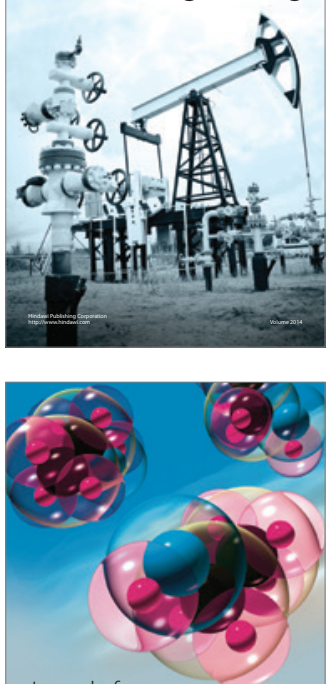

Fuels
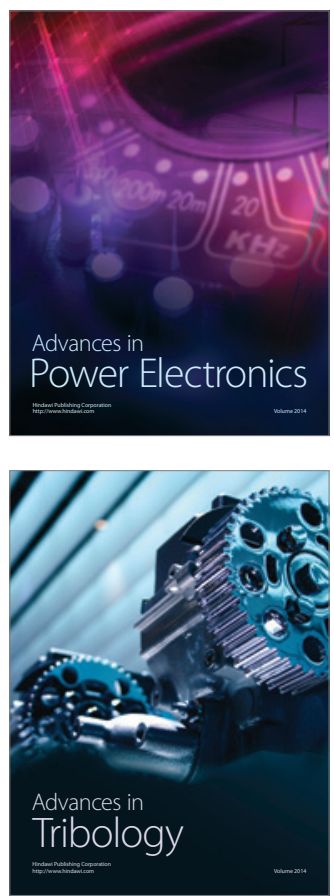

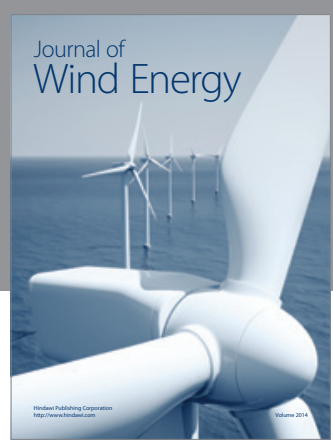

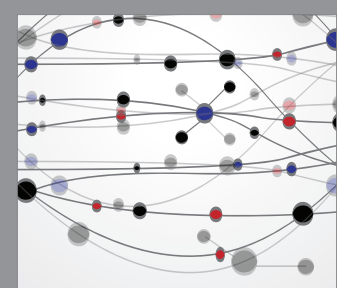

The Scientific World Journal

Submit your manuscripts at http://www.hindawi.com

Journal of

Structures
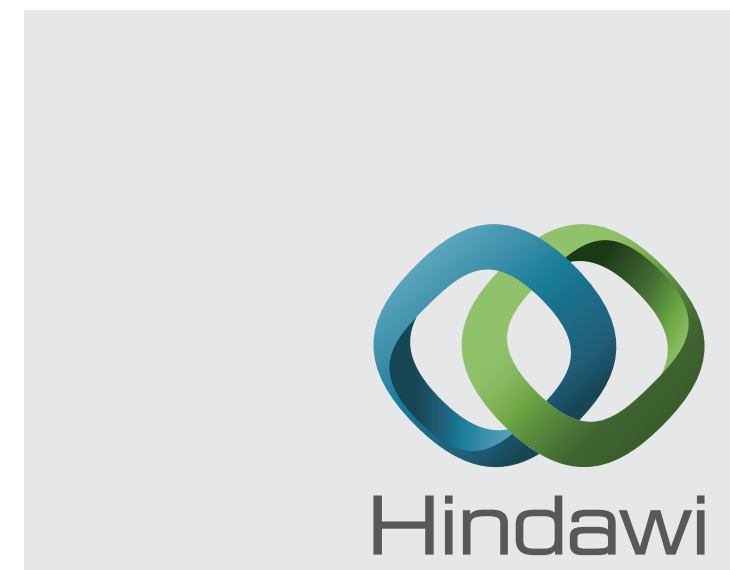

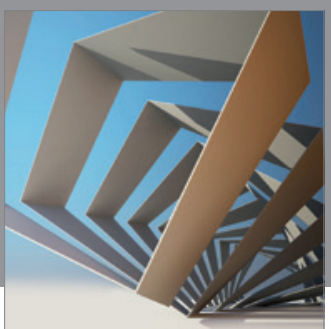

Rotating

Machinery
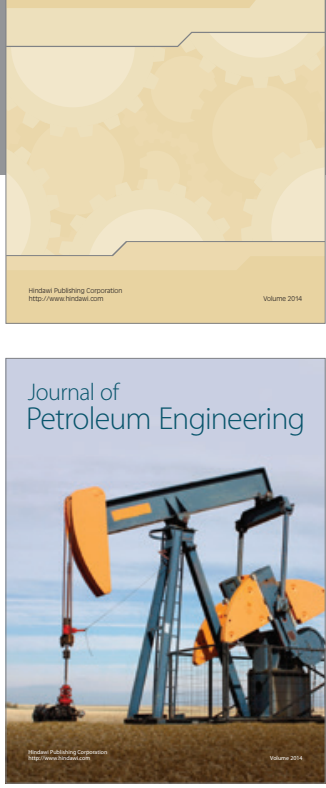

Journal of

Solar Energy
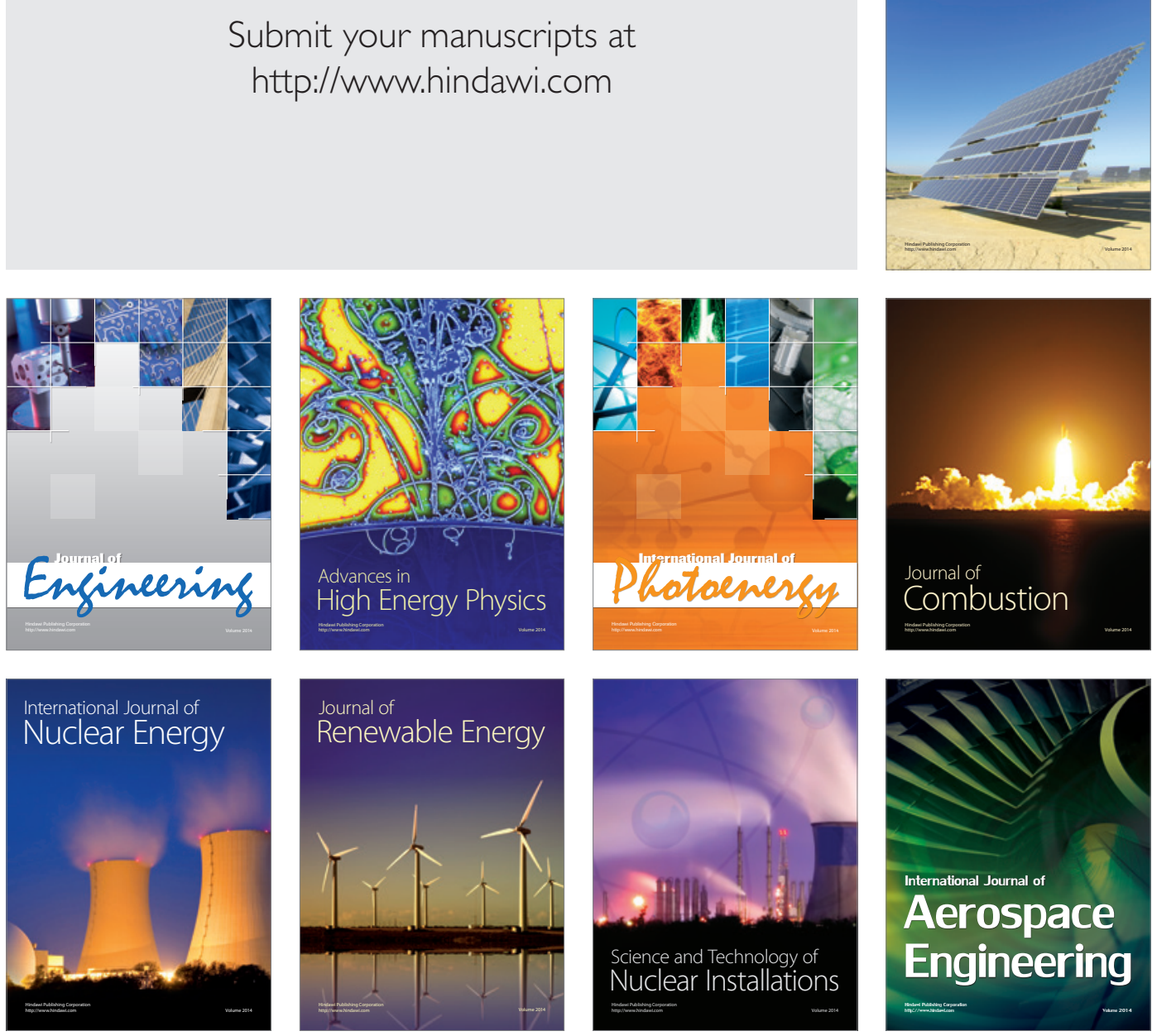